\title{
Satirical Discourse and Intertextuality: The Dialogic Construction of Satirical Authority in Die Fackel
}

\section{António Sousa Ribeiro}

To cite this article: António Sousa Ribeiro (2016) Satirical Discourse and Intertextuality: The Dialogic Construction of Satirical Authority in Die Fackel, Oxford German Studies, 45:4, 444-458, DOI: $10.1080 / 00787191.2016 .1243334$

To link to this article: http://dx.doi.org/10.1080/00787191.2016.1243334

曲 Published online: 03 Nov 2016.

Submit your article to this journal $[\pi$

Џll Article views: 8

Q View related articles $₫$

View Crossmark data $\nearrow$ 


\title{
SATIRICAL DISCOURSE AND INTERTEXTUALITY: THE DIALOGIC CONSTRUCTION OF SATIRICAL AUTHORITY IN DIE FACKEL
}

\author{
ANTÓNIO SOUSA Ribeiro \\ University of Coimbra
}

The essay focuses on an analysis of the dialogic nature of Karl Kraus's writing as an essential device for the construction of the identity and authority of the satirical self. Several exemples are given and discussed, drawing in particular from Shakespeare quotations and allusions in Die Fackel.

KeYWORDS: Karl Kraus, Satire, Quotation, Intertextuality, Authority, William Shakespeare

Reading Die Fackel as a literary text and, hence, choosing the specifically literary strategies at work in Kraus's texts as the object of study has long been a rather neglected perspective in Kraus scholarship. As a result, most studies on the Viennese satirist have tended, implicitly or explicitly, to postulate an absolute identity between the author and his work, an unreflected presupposition that needs to be effectively challenged. ${ }^{\mathrm{I}}$ In this essay I am going to concentrate on what seems to me a defining feature of Kraus's literary strategy: the dialogic construction of satirical authority. It is my argument that the identity of the omnipresent satirical voice in Die Fackel is inseparable from a close and intense relationship with a multiplicity of other voices, texts and discourses serving as its most peculiar 'echo chamber'. ${ }^{2} \mathrm{~A}$ consideration of this specific problem, while offering a vital perspective for an understanding of the fictional dimension in Kraus's satirical discourse, allows, at the same time, for a reevaluation of the satirist's stance within the modernist paradigm.

In the third volume (Das Augenspiel) of his autobiography, Elias Canetti argues that no satirist will grant the right to use of the word 'I' to anyone except

\footnotetext{
I A sustained critique of this tenacious postulate can be found in Edward Timms' pathbreaking studies. See Edward Timms, Karl Kraus, Apocalyptic Satirist. Culture and Catastrophe in Habsburg Vienna (New Haven and London: Yale University Press, I986); Karl Kraus, Apocalyptic Satirist. The Postwar Crisis and the Rise of the Swastika (New Haven and London: Yale University Press, 2005).

${ }^{2}$ I borrow the phrase from Roland Barthes (see Roland Barthes par Roland Barthes (Paris: Éditions du Seuil, I975), p. 78).
} 
himself. ${ }^{3}$ He obviously must have in mind Karl Kraus, an author who had been so influential in shaping his own formative years in Vienna. The same view had long ago been expressed by Walter Benjamin in his seminal Kraus essay: the editor of Die Fackel, Benjamin writes, is literally 'Ichbesessen'.${ }^{4}$ Such a stance, rhetorically and ethically legitimized by the state of a world where positive values can scarcely be discerned, has to be grounded in a sense of absolute and infallible authority. Canetti again:

Er [der Satiriker] verliert keinen Augenblick an den Gedanken, daß er vielleicht gar nicht Gott ist. ${ }^{5}$

There can be no doubt that, writing in the first person, Kraus is endorsing a strategy of demarcation and distinction that obsessively emphasizes the total isolation of a subject who can only find his own identity by intransigently opposing what he perceives as an essentially hostile world - hatred being the only remaining connection between the satirical self and that world. The assumedly monological character of Kraus's satire has accordingly always provided an important motif for Kraus criticism. Like Canetti, Theodor Haecker understands satire as an essentially monological type of discourse, 'wie die Predigt des berufenen Predigers, die keine Diskussion zuläßt'. ${ }^{6}$ The relevance of this motif for the repeated confrontation of Ferdinand Ebner, a philosopher of dialogue, with Karl Kraus is particularly striking. After reading Sprüche und Widersprüche, Ebner confides to his diary:

Aber heute wurde mir beim Lesen doch einiges klar: die ungeheure, ja nahezu absolute Icheinsamkeit dieser Geistigkeit. Spricht dieses Wort überhaupt noch, auch im ideellen Sinne, zu einem Du? Freilich, die Kraft der geistigen Selbstbehauptung dieses "Ichs" in seiner Einsamkeit, die es nahezu Du-los gemacht hat, diese Kraft muß man bestaunen, bewundern vielleicht auch. ${ }^{7}$

The 'solitude of the I' in Ebner's diagnosis stems from a notion of dialogue that is fundamentally ontological-existential and thus is very close to ideas that were being independently developed at the same time by Martin Buber around the concept of the 'dialogical principle'. ${ }^{8}$ In fact, the notion of a 'dialogical life' theorized by Buber can hardly be applied to Kraus; in this sense - and only in this sense - the almost unanimous stressing of Kraus's monologism is perfectly justified. If, however, we now turn to the specific discursive level, we will inevitably be led to face the solitude of the satirical self from a very different point of view, one defined by the seeming paradox aptly diagnosed by Canetti:

${ }^{3}$ Elias Canetti, Das Augenspiel. Lebensgeschichte I93 I-I937 (Frankfurt a.M.: Fischer, I988 [ $\left.\left.{ }^{\mathrm{I}} \mathrm{I} 985\right]\right)$, p. 22.

4 Walter Benjamin, 'Karl Kraus', in Gesammelte Schriften (Werkausgabe), ed. by Rolf Tiedemann and Hermann Schweppenhäuser, vol. 4 (Frankfurt a.M.: Suhrkamp, I980), p. 362.

5 Canetti, p. 23.

${ }^{6}$ Quoted by Gerald Stieg, Der Brenner und die Fackel. Ein Beitrag zur Wirkungsgeschichte von Karl Kraus (Salzburg: Otto Müller, I976), p. I66.

7 Ferdinand Ebner, 'Notizen, Tagebücher, Aphorismen', in Schriften, ed. by Franz Seyr, vol. 2 (Munich: Kösel, I963), p. 80I.

${ }^{8}$ See Martin Buber, Das dialogische Prinzip (Heidelberg: Lambert Schneider, 1984). 
Da er aber unterschiedslos alles zitierte, keine Stimme überhörte, keine unterdrückte, da sie alle in einer Art von kurioser Gleichberechtigung, abgesehen von Rang, Gewicht und Wert, nebeneinander bestanden, war Karl Kraus das unvergleichlich Lebendigste, was Wien damals zu bieten hatte. Es war das sonderbarste aller Paradoxe: dieser Mann, der soviel verachtete [...], ließ alle zu Worte kommen.?

As I have argued extensively elsewhere, Bakhtin's concept of dialogism offers the most suitable framework for an analysis of the interdiscursive dynamics described by Canetti. ${ }^{\text {IO }}$ In the sense of Bakhtin's category, we are no longer dealing with 'dialogue' in the hermeneutical sense (conducive, in the last resort, to a Gadamerian 'fusion of horizons'), but rather with radical alterity, with the clashing of ideologicaldiscursive levels that are, at least in part, incompatible. ${ }^{\text {II }}$ In this sense, 'double coding', following the definition Renate Lachmann in turn draws from Bakhtin, is the fundamental mark of dialogism; it will not be difficult to recognize this 'double coding' as a defining feature of Kraus's discourse, which recurrently uses an emphasis on the pre-marked and pre-structured nature of its material as a central device. ${ }^{\mathrm{I} 2}$ In other words, if it is to be effective, the authority of the satirist has to assert itself not in the terrain of abstract ideas and principles, but through a permanent confrontation on the concrete ground of the multiple utterances that compose the whole universe of public discourse of its time. So it is that Kraus's satire is full of voices, it is intrinsically dialogic. This implies that the permanent use of documentary quotation does not simply fulfil the function of making available a set of references and naming the exact source for Kraus's polemic and satiric indignation; more than that, it has a profoundly dramatic function, in that it provides his essays with a dynamic contrapuntal structure made of the clash of conflictual voices that has often more to do with the theatre than with the conventions of essayistic discourse. Kraus's approach to the scene of writing thus acquires a distinctly performative character, in that his use of language does not rest on the assumption of a pre-established meaning, but, instead, on the dialogic, polyphonic dynamics of a discursive space where a multitude of conflicting voices keeps reverberating.

9 Elias Canetti, 'Karl Kraus, Schule des Widerstands', in Das Gewissen der Worte. Essays (Frankfurt a.M.: Fischer, 1982 [1 1965]), p. 46.

ro António Sousa Ribeiro, 'Karl Kraus e Shakespeare. Uma poética da citação' (unpublished doctoral thesis, Universidade de Coimbra, I99I), especially pp. I43-202; see also my 'Karl Kraus und Shakespeare. Die Macht des Epigonen', in Karl Kraus: Diener der Sprache - Meister des Ethos, ed. by Joseph P. Strelka (Tübingen: Francke, I990), pp. 237-65. To my knowledge, the late Kurt Krolop was the first, and one of the very few, to suggest a consideration of the model of 'Menippean satire' as theorized by Bakhtin as an essential perspective for understanding the mode of construction of Kraus's satire (see Kurt Krolop, 'Dichtung und Satire bei Karl Kraus', in K. Krolop, Sprachsatire als Zeitsatire bei Karl Kraus. Neun Studien (Berlin: Akademie-Verlag, I987), p. 60). Strangely enough, Krolop did not further pursue the suggestion put forward in this text, first published in I97I, in any of the several groundbreaking Kraus essays he authored afterwards.

${ }^{\text {II }}$ For this indispensable distinction, see Paul de Man, 'Dialogue and Dialogism', Poetics Today, 4.I (I983), 99-107.

${ }^{12}$ For Lachmann's definition, see Dialogizität, ed. by Renate Lachmann (Munich: Fink, 1982), p. 8 . 
Kraus's well-known definition of the artist as the 'servant of the word' ('Diener am Wort' $)^{\mathrm{I} 3}$ — obviously a self-definition — puts forward a strong claim for an essentially non-instrumental conception of language. Although his stance towards the problem of language is characteristically optimistic - for Kraus too, as for Wittgenstein, 'the limits of language mean the limits of the world', but these limits, he believes, can always be pushed further and further - he is extremely conscious of the fact that the subject does not 'own' language, but is instead structured by language. The position of subordination he advocates, however, does not entail locating language in some metaphysical region only accessible by way of a mystical relationship. Language is, for Karl Kraus, not a metaphysical essence, but rather, in the first place, the ensemble of socially present discourses. ${ }^{\mathrm{I} 4}$ Both the Romantic quest for the 'original word' and the attraction of the avantgardes for the 'new' in the shape of some revolution of language are entirely alien to him. Instead, he favours 'das alte Wort', the apparently worn out word, the word marked by the path of its social circulation, in terms that would entirely fit Bakhtin's definition:

By no means does each member of the community apprehend the word as a neutral medium of the language system, free from intentions and untenanted by the voices of its previous users. Instead, he receives the word from another voice, a word full of that other voice. The word enters its context from another context, permeated with the intentions of other speakers. His own intention finds the word already occupied. ${ }^{\mathrm{I}} 5$

The dialogic device summed up by Kraus in the paradoxical metaphor of the 'birth of the old word' ('Geburt des alten Wortes') defines the overall discursive strategy in Die Fackel. The artist of the word has no material apart from the one offered by the multiplicity of discourses present in the social field of his time and place; as an artist, his relationship to that material is anything but passive. 'Geburt des alten Wortes' thus alludes to the dialogic process of meaning production through challenging the mechanisms of indifferent repetition at work in current discourse. 'Giving birth' again to the word entails, in this sense, a polemical and satirical gesture, implying an essentially combative attitude. One of Kraus's many aphorisms on language highlights the peculiar dialectics of this dialogic relation:

Ich beherrsche nur die Sprache der andern. Die meinige macht mit mir, was sie will. ${ }^{\text {I6 }}$

In her full-length study of Kraus's aphoristic production, Petra Kipphoff compares this aphorism with some other analogous instances, coming to the conclusion

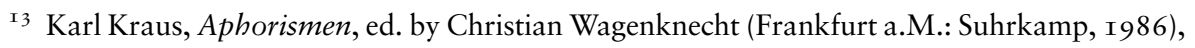
p. II6.

I4 The all too current emphasis on Kraus's 'language mysticism' - a persistent critical cliché I cannot discuss here in detail — is based on a simplistic, literal interpretation of some of the satirist's statements, rather than on an analysis of his verbal practice.

${ }^{15}$ M. M. Bakthin, 'Discourse Typology in Prose', in Readings in Russian Poetics (Formalist and Structuralist Views), ed. by L. Matejka and K. Pomorska (Cambridge, Mass.: MIT Press, I97I), p. I95.

I6 Aphorismen, p. 326. 
that, in this particular case, the mark of the first person singular makes it at once 'the most subjective' and 'the most indisputable' among similar aphorisms:

Auch gegen die absurdesten Aussprüche läßt sich nichts einwenden, wenn Kraus von "Ich" redet. ${ }^{\mathrm{I} 7}$

Kipphoff's diagnosis is hardly controversial; it will not, however, be of much service unless one pushes the inquiry much further. Why is the authority of this 'I' so overwhelming? The answer cannot possibly lie in the simple fact of it being asserted; it lies, I would suggest, in the way this ' $I$ ' is staged in the scene of discourse. At first sight, in the example I gave, the adverb of exclusion would seem to mark the limits of the satirist's authority. This authority would only be effective, it seems, when applied to a language use susceptible of satirical distanciation. The apparently all-powerful ' $\mathrm{I}$ ' of the first half appears in the second as in turn utterly dependent on some higher authority - a contrast emphasized by the chiasmatic structure of the aphorism. But since 'mastering' the language of others implies the use of 'his own' language, since the source of that 'I's authority is his readiness to obey, the I is not defined subjectively — it is, instead, defined through the medium of language. 'Serving' language has an immanently dialogic sense: the reason 'his' language makes of him what it wants lies, namely, in the fact of this language not being really 'his'. His authority is not, therefore, the given authority of an absolute subject, it is defined by the satirist's ability to engage successfully in the play of discourse, guided by a notion of non-instrumental language he derives from a productive appropriation of literary tradition. In this sense, the two distinct halves of the aphorism are not independent from one another: the uncompromising distinction between two 'types of language' - the difference between 'mastering' and 'being mastered' - thus points in the end at two poles of one and the same process, stressing the essential 'social ubiquity' ${ }^{\mathrm{I} 8}$ of language use. ${ }^{\mathrm{I9}}$

The stance of authority taken by the satirist does not, in this sense, rest on a transcendental basis, it is produced and asserted through the practice of discourse and within the specific literary space delimited by that practice. Bertolt Brecht has provided perhaps the most incisive definition for this mechanism when he referred to the Krausian literary space as the space of the tribunal. But the authority presiding over this tribunal is, in Brecht's formulation, not prefixed, it is itself a product of

\footnotetext{
17 Petra Kipphoff, Der Aphorismus im Werk von Karl Kraus (doctoral thesis, University of Munich, I961), pp. 77-78.

${ }^{18}$ V. N. Voloshinov, Marxism and the Philosophy of Language, trans. L. Matejka and I. R. Titunik (New York and London: Seminar Press, I973), p. I9.

I9 This would imply that the current distinction between 'affirmative' and 'satiric' quotation in Karl Kraus, first made by Benjamin and afterwards adopted by many, be not taken, as is often the case, in absolute terms. Both forms, while certainly distinct, are aspects of the same literary strategy at work throughout in Die Fackel — the strategy, which defines the essential modernity of Kraus's writing, of what I call 'a poetics of quotation'. In this sense, Sigurd Paul Scheichl's highly perceptive analysis of 'Stilbruch' in Karl Kraus suffers nonetheless from the use of an inadequate framework derived from 'monological' stylistics. Indeed, so my argument goes, the use of a multiplicity of registers and of verbal material from many different sources implies no 'breaking of style', it is, on the contrary, a defining component of dialogical style (see Sigurd Paul Scheichl, 'Der Stilbruch als Stilmittel bei Karl Kraus', in Karl Kraus in neuer Sicht ed. by S. P. Scheichl and Edward Timms (Munich: Text+Kritik, I986), pp. I28-42.
} 
Kraus's writing, insofar as it has 'been demonstrated by many examples, and not put in doubt by a single one':

Solche Autorität besitzt Kraus in dem Maße, dass schon das äußere Bild einer Seite der mit unendlicher Sorgfalt gedruckten "Fackel" im Leser den Eindruck der Ordnung und der Lauterkeit hervorruft, welcher Eindruck vor dem Lesen entsteht, weil er so oft nach ihm entstanden ist. ${ }^{20}$

The satirical relation with the 'language of others', materialized in the sophisticated modes of satirical quotation Die Fackel was to develop, is a dialogic one in Bakhtin's sense: in order to demonstrate the inadequacy and illegitimacy of current discourse, above all the discourse of the press, satire must recontextualize it within its own space. In the process, satire becomes anthropophagic ${ }^{2 \mathrm{I}}$ also in the sense that the ability to engage with a plurality of discourses becomes its condition of existence. Satirical authority emerges from the 'theatrical' appropriation of those other voices or discourses. In fact, in the aesthetic space of modernity, that authority no longer rests on extra-aesthetic, fixed criteria. It is achieved through the staging of the self within language, through the play of dialogism - authority, in sum, is not simply given, as a presupposition of discourse, it is, first and foremost, an effect of discourse. The power of mimesis materialized in Kraus's satirical writing is not based, in this sense, on the voice of a single stance playing the role of a judge, or a god, but rather on the assuming of the mobility of a plurality of roles.

This mobility is an essential feature of Kraus's writing, testifying to the satirist's ability to perform different roles, and to perform them simultaneously. In the final verses of the great retrospective poem 'Nach dreißig Jahren', this diversity of roles is emphatically alluded to:

Noch fernere Jahre stör' ich diesen Frieden,

Hier Kämpfer, Künstler, Narr, und dort die Bürger! ${ }^{22}$

In the triad 'fighter, artist, fool' the artist builds the centre of two apparently antagonistic poles that become associated by the synonymic structure of the sentence. At the same time, the triad is also structured in the way of a crescendo, which, reaching its climax in the sharp caesura dividing the line, decisively foregrounds the term 'fool', a term corresponding to a radically marginal position in massified society. The figure of the fool as a paradoxical site of truth, because he is able to turn upside down the apparent logic of instrumental rationality dominating society, is in Karl Kraus of an obvious Shakespearean origin. This is a figure indissociable from the one of the actor, connoting the mobility and flexibility of Kraus's satirical technique.

${ }^{20}$ Bertolt Brecht, 'Karl Kraus', Gesammelte Werke, vol. I9 (Frankfurt a.M.: Suhrkamp, I975), p. 43 I.

${ }^{21}$ The telling equation between the satirist and the cannibal, drawn by Walter Benjamin ('Karl Kraus', p. 355), is clearly inspired by Kraus.

${ }^{22}$ Karl Kraus, Gedichte, ed. Christian Wagenknecht (Frankfurt a.M.: Suhrkamp, I989), p. 635 . 
This rhetorical mobility implies that the reference to the universe of tradition, and, specifically, of literary tradition, is also never simply postulated. Accordingly, that reference is not a simple ornament or an appeal to authority, it is always also acted out in intertextual construction. The much debated notion of the 'Origin' ('Ursprung') points, in this sense, not to a given a-historical essence, but, as some have consistently argued, to a utopian horizon ensuring that value and meaning are real possibilities, achievable through the power of language. ${ }^{23}$ The fact that literary tradition - the literary tradition Kraus selectively appropriates as a 'servant of the word' - appears as a site of that 'Origin' does not imply some kind of blind reverence to the past. Indeed, the preservation of tradition is inseparable from the game of intertextuality (i.e. is dependent on the incorporation of its textual material in ever new contexts of discourse), and is put at the service of specific satiric strategies. I cannot dwell here upon the multiple functions of literary quotation in Kraus's writings. I will simply concentrate on the use of literary quotation as a device for the dialogic definition of the identity and the authority of the satirical voice, illustrating my argument with an inevitably brief selection of relevant examples.

The satirical mask that Kraus most intimately (and from early on) turned into his own - almost to the point of identification — was the mask of Shakespeare's Timon of Athens. But he also resorts to many other less spectacular masks, often at a microtextual level, to establish the identity of the self figuring as the voice of enunciation of satirical writing. Many of these intertextual masks are drawn from dramatic literature, which more directly allows for a direct impersonation and, thus, for the emphasizing of the theatricality of discourse that is Kraus's avowed aim. But this need not be so - sometimes the assertion of satirical identity rests upon far less marked devices. Even the appropriation of current quotations implicitly contributes to the rhetorical stylization of the instance conducting the play of intertextuality. Let us consider the following example:

Den Journalisten nahm ein Gott zu leiden, was sie sagen. ${ }^{24}$

The allusion here is to two famous lines from Goethe's Torquato Tasso:

Und wenn der Mensch in seiner Qual verstummt, gab mir ein Gott zu sagen, wie ich leide.

${ }^{23}$ I cannot dwell here upon the difficult questions raised by Kraus's 'Ursprung' metaphor. I will just point out that it has to be understood as the conscious aesthetic construction of a utopian horizon. Indeed, as I have argued elsewhere, 'to think, as so many critics seem to do, that [Kraus] cherished a "mystical" belief in something as a lost Golden Age is so pathetically naive as to assume that Rousseau really saw in his "good savage" a substantial historical entity' (António Ribeiro, 'Karl Kraus and Modernism: A Reassessment', in The Turn of the Century. Modernism and Modernity in Literature and the Arts, ed. by Christian Berg et al. (Berlin: de Gruyter, I995), p. I46). See also John Pizer, "Ursprung ist das Ziel”. Karl Kraus's Concept of Origin', Modern Austrian Literature, 27.I (I994), I-2I.

${ }^{24}$ Die Fackel, n²6I-62, I908, p. I 4 (quoted henceforth simply with the usual F, followed by issue numbers, date, and page reference). 
The passage quoted occurs in one of those many polemics against the press that build one of the essential pillars of Die Fackel's satirical endeavour. Language criticism, as is well known, is a vital component of that polemics - criticism, that is, of a logic of discourse based on an irresponsible, because purely instrumental and gratuitous relation with language. The modified and inverted Goethe quotation alludes to this kind of relation, in its mechanical divorce from actual experience, but, more than that, in doing so, it delineates by contrast another figure, the figure of the antijournalist, coincident with the persona of the satirist, who can legitimately claim Goethe's formulation in its original integrity of form and content - and who is thus author-ized, entitled to master the 'language of others' through critical discourse precisely because he entertains a meaningful relation to language.

But let us consider another, slightly different example. In the satire 'Hans Müller in Schönbrunn' Kraus describes some details of the lawsuit waged against him by Hans Müller - a writer that now rests in most deserved oblivion, but who, for a while, was a celebrated figure, especially during World War I, as the author of the nationalistic drama Könige. ${ }^{25}$ The following passage alludes to the behaviour of the editor of Die Fackel in court:

[...] in dem Bewußtein, wenn die Könige bau'n, nur niederreißen zu können saß ich da [...] (F52I-30, I920, 42)

This passage can only be properly understood if we recall its intertextual matrix, a much quoted line from Schiller's xenion 'Kant und seine Ausleger':

Wie doch ein einziger Reicher so viele Bettler in Nahrung

Setzt! Wenn die Könige baun, haben die Kärrner zu tun.

The irony evidently rests, in the first place, in the allusion to the title of the play that had provided for Müller's celebrity. But there is, of course, more to it. Kraus is also playing with a current reproach against the satirical mode, the reproach, repeatedly levelled against himself, that the satirist can only 'destroy' and is unable to 'build'. The implicit refusal of the role of the 'cart-driver' corresponds to the denunciation of the ideological mystification implied in the claim that satire should assume a 'constructive' function and implicitly legitimizes the destructive stance of satire after all, the form of the allusion to the contrast between the great man (Kant) and the smallness of those he keeps busy places the satirical self firmly at the positive pole. The text where this allusion occurs presents, in its polemical nature, a very clear-cut case where the textual 'I' would seem totally identical with the author himself. While this is in a sense true - Kraus is, after all, recounting a piece of his actual experience as editor of Die Fackel - , a consideration of the microstructure of the text reveals how, notwithstanding, that 'I' undergoes an unmistakable process of rhetorical stylization through the help of devices such as the allusion I have pointed out.

${ }^{25}$ Hans Müller is a recurrent object of satire in Die letzten Tage der Menschheit. See, in particular, Act I, scene 25 . 
These few examples (which could easily be multiplied) demonstrate how an important part of Kraus's discursive energy is applied to defining the position of the subject of enunciation, so as to evidence the 'natural' authority and legitimacy of the satirical attitude. This will, however, only be apparent to a literary reading capable of confronting the complex web of rhetorical reference. The strategy of selfstylization of the satirist becomes even more evident when longer quotations are used, and, in particular, when the satirical self assumes more directly the role of this or that dramatic character with a well-defined topical value.

One quite simple case is the epigraph to the text 'Die Wahlreform'. Written in I906, this text takes the form of an answer to an open letter by Robert Scheu, a collaborator of Die Fackel and would-be author of the first full-length study of Kraus, published in the magazine itself in 1909 (F277-78, I-24). 'Die Wahlreform' is an outstanding reference for the process of programmatic clarification and reorientation undergone in those years by Die Fackel - its 'ästhetische Wendung', as Kraus would ironically label it. Scheu, a publicist close to Austrian social democracy, had asked that Kraus take position about a burning issue of political actuality, the reform of the electoral system. In his answer, the editor of Die Fackel, after printing Scheu's open letter, refuses the role he is offered, stressing instead the primacy of cultural critique and of an aesthetic point of view over the concern with political and social analysis that had marked his initial years. This answer carries as its epigraph the satirical variation of a well-known passage from the first part of Goethe's Faust, a piece of the conversation between Faust and Margarete on the former's understanding of religion. Kraus quotes eight lines of the dialogue, with only a slight change in the first line ('Nun sag', wie hast du's mit der Religion?'), designed to adapt Faust's words to the new context:

\section{Nun sag', wie hast du's mit der Wahlreform? (FI94, I906, 6)}

The function of this epigraph, that directly evokes the whole scene and the dramatic situation, lies not only in the identification with Faust with all the associations it carries along, but, at the same time, in placing the interlocutor from the outset in the inferior position of someone who is simply naively echoing conventional rules and unquestioned values. The problem of the electoral reform stands metonymically for politics in general, a concern Kraus is now discarding as a kind of irrational religion, alien to life and its concrete driving forces. The stance of benevolent superiority regarding the 'Gretchenfrage' put forward by R. Scheu, is powerfully enhanced by the initial quotation which defines and at once legitimizes an autonomous position grounded on the refusal of current convention and of established rules. Once again the play of intertextuality brings vital support to the 'authorization' of the subject of enunciation.

The dynamics of literary allusion pertains, as a rule, to a familiar repertoire: above all to the Bible, ${ }^{26}$ to the German classical authors, Goethe and Schiller, and, very

${ }^{26}$ A beautiful example, among others, is the satirical identification with Samson in a text of 1924: 'Philister über mir, die mich mit den sieben Stricken eines Verbots binden wollen. Aber ich habe schon dreihundert politische Füchse gefangen und mit eines Esels Kinnbacken, von einem der Herrschaften abgelegt, schlug ich tausend Journalisten; denn "ich habe einmal eine rechte Sache wider die Philister" [...]' (F657-67, I 924, 77). 
often, to Shakespeare (the 'third classic', as he came to be firmly established in German culture in the course of the nineteenth century, mainly through the so-called 'Schlegel-Tieck' translation, a text with outright canonical value for Kraus). ${ }^{27}$ On the other hand, if we take a glance at the many passages where the main function of quotation lies in the impersonation of a literary person of archetypical significance, we shall easily reach the conclusion that Kraus resorts above all to figures occupying a marginal position vis-à-vis society, a marginality that allows an interplay with his own quest for autonomy and with the definition of his aesthetic position as one of embattled isolation. Standing, for one reason or another, aside from society provides a decisive motif for dialogical assimilation: among many other examples, Kraus assumes the role of the villain Franz Moor in Schiller's Die Räuber (F339-40, I9I I, 55) or he puts on the mask of Wilhelm Tell, glossing the passage in Schiller's drama where the liberator is waiting in ambush for the tyrant to come, hoping for an opportunity to kill him. ${ }^{28}$

The main source for this type of intertextual strategy is to be found in Shakespeare. In one very interesting passage, analogous to those just mentioned, the character of Richard III provides the focusing voice. Kraus quotes some extracts from the initial monologue, where the future king, putting on the archetypical mask of the 'Vice' of medieval tradition, unveils his sinister intentions and his disgust at the prevailing peaceful atmosphere:

Der Tölpel hat recht, es war ein Entschluß, ich bin nur aus Unfähigkeit, für die Zeit zu wirken, ihr Feind geworden, und darum, weil ich nicht als ein Verliebter konnt' kürzen diese fein beredten Tage, war ich gewillt ein Bösewicht zu werden, und feind den eitlen Freuden dieser Tage. Ich nun, in dieser schlaffen Friedenszeit, weiß keine Lust, die Zeit mir zu vertreiben, als meinen Schatten in der Sonne spähn und meine eigne Mißgestalt erörtern. Nun möchte ich, entstellt von einem Zeichner, so um dies schöne Ebenmaß verkürzt, dass Hunde bellen, hink' ich wo vorbei - auch noch alle diese Hunde auf einen Platz treiben und in einer Schlinge erwürgen. (F374-75, I9I3, 38)

Kraus's quotations play ironically with the stereotype of the satirist as someone moved by base passions and rancors. But there is not only irony: taking on momentarily the mask of the Shakespearean villain, the satirist is, as in so many other cases, using the form of quotation for a subtle pairing of the ironical with the pathetic mode of satire. This is an instance that clearly demonstrates the correctness of the assertion that the meaning of quotation is not the meaning of an utterance but the meaning of the repetition of an utterance. ${ }^{29}$ The ironic effect lies in repetition, in assimilation within another context of discourse; if the quotation were not to be perceived as such, that specific reading would not be possible. The subject of the second

27 For a full list of Shakespeare allusions and references in Die Fackel, see my 'Shakespeare in der Fackel. Ein Register', Kraus-Hefte, 64, I992, I-6. For some details of Kraus's use of 'SchlegelTieck', see my notes in the same issue, pp. I I-I4.

28 'Wie durch die hohle Gasse ziehen sie alle ihres Weges fort an ihr Geschäft und meines ist der Mord' (F339-40, I9II, 2I).

29 See for this definition Antoine Compagnon, La seconde main, ou le travail de la citation (Paris: Seuil, I979), p. 86. 
enunciation, Die Fackel's satirical self does not, of course, identify with the villain: he takes advantage, on the rhetorical level, of the strongly emotional character of that villain's declaration of his marginal position, of his hatred of 'the idle pleasures of these days', for the definition of his own distanced stance, which in this way proves to be not only circumstancial, but principled, as supported by the assumption of an archetypical mask.

Putting on a Shakespearean mask means in such cases for Kraus putting on a rhetorical mask, assuming a relationship that is primarily of a textual nature, and that is by no means to be confused with existential identification. This seems to me very clear, to provide another example, in the passages where Kraus assumes the role of Coriolanus. The interpretation of Leopold Liegler, who detects in the relation to this role a 'deeply felt identification', ${ }^{30}$ is, to my mind, wholly misleading. The few quotations from Coriolanus in Die Fackel ${ }^{3 \mathrm{I}}$ in no way reveal such a deep identification: Kraus simply uses the character as the paradigm of a refusal of current codes, of accepted ways of behaviour and established social consensus. In his Betrachtungen eines Unpolitischen, Thomas Mann takes Coriolanus as the model of an aristocratic contempt for 'the masses' that mirrors his own elitist stance in his defence of 'Kultur' and the 'ideas of I9I4' against the spirit of democracy. ${ }^{32}$ Such an empathy will not be found in Karl Kraus: the satirist retains just the element of self-marginalization caused by incompatibility with current communication practices, as an archetypical model for the essential gesture defining his own position, the gesture of isolation. ${ }^{33}$

Besides the special case of Timon of Athens, two other Shakespeare dramas are of the utmost importance for the intertextual consolidation of the identity and authority of Die Fackel's satirical subject: Hamlet and King Lear. The role of Hamlet as the deconstructor of apparent truths and as a radical disturber of the supposed harmony of his world, in his anguished search for a meaning that calls for the same 'throwing down of façades' defined by Kraus as the core of his satirical project, ${ }^{34}$ could not be more suitable as a mask for the satirist. Again, this does not entail adopting Hamlet's identity, but rather taking advantage of a rhetorical disposition. There are several examples of the assuming of Hamlet's mask, beginning with various uses of the words with which Hamlet draws almost apocalyptical conclusions from his encounter with the ghost of his father ('The time is out of joint, $\mathrm{O}$, cursed spite,/That ever I was born to set it right!') Whether in the ironic or in the

30 Leopold Liegler, Karl Kraus und sein Werk (Vienna: Richard Lányi, I920), p. 4 I I.

${ }^{31}$ See above all F368-69, I9I3, 56; F890-905, I934, 44; F917-22, I936, I06-07.

32 See Thomas Mann, Betrachtungen eines Unpolitischen, Gesammelte Werke in dreizehn Bänden, vol. XII (Frankfurt a.M.: Fischer, I974), pp. 368-69.

33 The terms of Stanley Fish's analysis can be applied pretty directly to Kraus's use of this and other Shakespearean allusions: 'Coriolanus' every illocutionary gesture is one that declares his disinclination to implicate himself in the reciprocal web of obligations that is the content of the system of conventional speech acts. To put it simply, Coriolanus is always doing things (with words) to set himself apart.' (Stanley Fish, 'How to Do Things with Austin and Searle: Speech-Act Theory and Literary Criticism', in Is There a Text in This Class? The Authority of Interpretive Communities (Cambridge, MA: Harvard University Press, I980), p. 213).

34 See e.g. F3II-I2, I9I0, I3: 'Ich haue Fassaden ein und mache tabula rasa mit den Menschlichkeiten.' 
pathetic mode, this quotation allows in various ways for the projection of a satirical identity. This is also the case where it does not appear literally but is simply implied by an allusion to the dramatic context. One very good example is a passage from 'Mein Abenteuer mit Schober'. In this text Kraus refers to his combat with Vienna's chief of police, the man directly responsible for the massacre of February I927 demonstrators, as an isolated struggle, deserted by all his supposed allies. This central motif is emphasized by an allusion that inverts Hamlet's situation:

[...] wenn Gespenster sich um Mitternacht fürchten, weil ein Mensch umgeht, und ihn keiner gesehen haben will — den Finger auf dem Mund und alle schwörend auf ein Schwert, ,niemals von dem, was sie gehört, zu sprechen“. Muß ich just, wann und wo sie wirken, zur Welt gekommen sein! Warum nicht fünfzig Jahre später? Warum nicht gleich auf die Nachwelt? (F77I76 , I927, I4)

The image of a world threatened by absolute chaos is powerfully enhanced by this complex allusion, where the satirical self implicitly takes the role both of Hamlet and of his father's ghost, but in such a way as to reinforce the topos of the world turned upside down, since he appears as the only real man in a world inhabited by ghosts and thus has no one to hear his grievances. By implication the Shakespeare allusion automatically puts the satirical self 'in the right', backing up his claim for an authority that only posterity will be able to acknowledge.

The allusion to the dramatic universe of Hamlet also implies that the state of disorder will not last forever - somehow, a new order will eventually emerge out of chaos. In his use of quotations and allusions from Hamlet Kraus takes advantage both of the role of the avenger, ${ }^{35}$ and, on the other hand, with no less emotional engagement, of the role of a commentator. The mask from Hamlet with which Kraus most profoundly identifies - Horatio - belongs to the latter sort. Apart from other, less crucial instances, it will be enough to point to the quotation of Horatio's final report in the central text 'Weltgericht', of October I9 I 8 (F499-500, 3-4) and, afterwards, in two essential passages in Die letzten Tage der Menschbeit. ${ }^{36}$ Kraus does not reject here the role of a judge or an avenger, but he assumes above all the role of the surviving witness, burdened with the task of preserving the memory of the tragedy. The topos of history as an absurd nightmare derived by Kraus from Shakespeare's dramatic universe emphasizes the salience of Horatio's role, as the lucid witness, someone not directly involved in the action and whose moral superiority allows him to emerge from the nightmare with the capacity of transmitting to those yet ignorant the report of the dreadful events, so that the

35 This is in part the role of Hamlet himself, but, more markedly, of Fortinbras, a character who is several times alluded to in Die Fackel. For a prominent example, see the conclusion of 'Die chinesische Mauer': 'Ein Fortinbras naht, auf dem Trümmerfeld der Sünde die Herrschaft anzutreten. "Wo ist dies Schauspiel?" Aber damit lebe, was begraben ist, muss er dem Toten erst den Todesstoß geben. Seine Hand greift nach der Kultur, die ihn durch ihr letztes Augendrehn versöhnen möchte, und würgt sie mit Lust' (F285-86, I909, I6).

${ }^{6}$ Karl Kraus, Die letzten Tage der Menschbeit, ed. by Christian Wagenknecht (Frankfurt a.M.: Suhrkamp, I986), pp. I I, 68 I. 
new order will not be grounded on forgetfulness. In the twenties, Horatio's mask would thus become for Kraus the mask of the implacable prosecutor: the insistence on preserving the memory of the absurd of a criminal history, of the 'tragic Carnaval' (Kraus's phrase for World War I), entails, by itself, the most violent denunciation of a time intent on forgetting.

King Lear, a tragedy where any idea of reconciliation is consistently and radically denied, is the Shakespearean drama that, along with Hamlet and Timon, provides the richest support for the topos of the incurable conflict with a world turned upside down that defines the role of the satirist. At the same time, it is also the richest source for apocalyptic images directly assimilable by satirical discourse. The relevance of Lear's character for Kraus as a satirical archetype quite close to Timon has to date not been properly emphasized in Kraus scholarship. Lear's tragic career is read by Kraus as a learning process, in the course of which the renunciation of the signs of power and the subsequent disintegration of the king's identity, culminating in madness, are a presupposition of the assertion of a different form of authority, legitimized by the experience of suffering and of the exclusion from a social order whose stable rules can now be characterized as deeply problematic. Having become less than nothing, the former sovereign assumes the tremendous voice of the satirist, capable of seeing with ruthless lucidity behind the façades of the conventional systems of social representation. Excess and madness are signs for the refusal to accept the mechanisms of representation governing the apparent normality of things: they are the 'natural' condition of a world vision which, as in the case of Lear, once awoken from initial blindness, becomes, through a process of suffering, capable of those paradoxical forms of understanding that define the satirical perspective.

The perception of a world turned upside down, whose truth is hidden behind the mechanics of convention, and thus, in order to be articulated, asks for a stance of radical excentricity materialized in the figure of the madman or the fool, archetypically defines the authority of the satirical voice. No wonder, therefore, that, among the many quotations from Lear detectable in Die Fackel, the more frequent are those from the sixth scene of Act IV, the scene where the satirical import of Lear's role is absolutely central. Even when, as in the epigraph of 'Sittlichkeit und Kriminalität' (FI I 5, I902, I-2), the mode of quotation is less "theatrical", not directly assimilated by the satirical voice, it becomes evident that the function of Lear's voice as an archetype of satire is to bring support to the self-stylization of the satirist as an instance of authority.

The same is even more true of Timon; in this case, however, as I have already suggested, the dynamics of identification attains almost existential significance. The vision of the misanthrope as someone whose desire for the absolute has been betrayed and who is thus led to curse all humankind perfectly adjusts to the construction of satirical identity - all the more so when the satirist is forced to recognize his impotence in influencing in practice the world he lives in, and, in consequence, is more and more led to seek refuge in the realm of art and of language. One should, however, bear in mind that this identification is never complete: an element of distance is always there and the rhetorical and fictional dimension of the play of intertextuality should be apparent to any close reading, even if Kraus's interpretation of Timon's character is totally unproblematic. In fact, he never faces the question of Timon's tragic fault or, even less, favours a reading of the 
drama as a satire on the satirist ${ }^{37}$ - the primordial and mythical dimension of the character as a 'defeated verbal Titan' is for him the absolutely defining trace. ${ }^{38}$

Timon's literally immoderate relation to reality, his essential inability to compromise, define the paradigm on to which Kraus's own aesthetic-satirical stance is projected. One should, however, not forget that Timon's absolute solipsism is assumed by Kraus in the mode of quotation and allusion, with its own dialectics of simultaneous proximity and distance. That solipsism, in other words, to use Wittgenstein's famous dichotomy, is not only said - it is also shown. Thus, even the very strong identification with Timon is never absolute. ${ }^{39}$

A most telling episode towards the end of Kraus's career may be briefly mentioned in this context. The polemics against his own audiences builds a red thread throughout Kraus's entire career, but in the evening of I 6 th of November I 930 he would bring this to a peak. He had advertised a reading from his own writings and there was a full house. But he started with an introduction he named 'Timons Mahl' where he harshly rebuked the audience for flooding into such readings hoping to get satisfaction from polemic-satirical content with a direct connection to themes of actuality, while neglecting to attend his 'Theater der Dichtung' and thus forsaking the possibility of the enriching experience of contacting with Shakespeare's poetic visions. He then announced that the evening's programme had been changed and that he would proceed to read Timon of Athens, instead of from his own writings.

One may recall that the central scene of Shakespeare's play is set around the banquet offered by Timon to the false friends that have refused to help him in times of need and now come back thinking he has become an affluent man again. There is, however, no food on the table; the bowls are filled with stones and hot water which Timon throws at the false friends as he drives them away from his house, while hurling the most violent curses at them. Kraus's performative gesture translates this situation into the context of the relationship to his own audience and to Viennese and Austrian society in general. The mimetic gesture is an act of quotation by the means of which Kraus projects his identity as an author against the background of the figure of the Shakespearean misanthrope, thus incorporating Shakespeare's dramatic universe into his own scene of writing. One might thus say, in a sense, that Kraus construes Shakespeare as his own heteronymic counterpart. Since, however, the archetypical reference is not simply assimilated within a logics of continuity, but, on the contrary, is literally translated, i.e. moved and reconstructed within the new framework of the intentionality of Kraus's own discourse, the mask of the misanthrope, while placing the satirical voice in an undisputed place of authority, also, at the same time, makes almost tragically visible the limits of that authority.

37 See the chapter 'The Satirist Satirized' in Robert C. Elliot, The Power of Satire. Magic, Ritual, Art (Princeton: Princeton University Press, I960).

${ }^{8}$ The phrase is Agostino Lombardo's, 'The Two Utopias of Timon of Athens', Shakespeare Jabrbuch, I 20 (1984), 85-89 (p. 89).

39 This exposes the fundamental inadequacy of the current definition of Kraus as the 'Timon of Vienna'. I deal extensively with the topic of the significance of Timon for the definition of Kraus's satirical stance in the final chapter ("Timon of Vienna?" Kraus in the role of the misanthrope") of my Karl Kraus e Shakespeare, pp. 679-788. On this question see also Gerald Stieg, 'Le Timon de Vienne', in Figures de la singularité, ed. by Rolf Wintermeyer and Michel Kauffmann (Paris: Sorbonne Nouvelle, 20I4), pp. I9I-96. 
This assertion of authority in a way that, at the same time, points to its own essential precariousness becomes most apparent in the use of Timon's mask in the thirties, when the temptation of silence is strongest. When, as in verses written in 1935 that were published for the first time only in the eighties, the satirist expresses his hope that his name may soon disappear 'wie Spreu im Winde', ${ }^{\circ}$ he is still assuming a stance of authority. But this manifestly retains nothing of the prophetic or God-like stance so often associated with Kraus's image but, instead, incorporates an acute awareness of its own ambivalent nature.

In the longest and most problematic text in Die Fackel, the famous 'Warum Die Fackel nicht erscheint' from I934, the tension between the authority of the satirical voice as a pressupposition of discourse and, on the other hand, the final assumption of its essential precariousness reaches its climax. The satirist resists once again the loss of identity entailed by the ever stronger attraction of silence, but, in doing so, is more and more led to resort to other voices, that will once again allow him not to silence that which cannot be spoken of. That is why the much-discussed 1934 issue $($ F890-905) is the one where the relevance of quotation and allusion above all taken from Goethe, but also, among others, from Shakespeare - is most salient, the one where the dialogic foundation of the rhetorical construction of the identity and authority of the satirical voice is most evident.

This dialogical foundation, which I could but briefly sketch here in one of its main aspects, and which has to date not yet been awarded the thorough analytical attention it deserves, is an essential part of Kraus's answer to the crisis of meaning in the aesthetic context of modernity - the context where his work is distinctly rooted. ${ }^{4 \mathrm{I}}$ The poetics of quotation which is developed along the pages of Die Fackel in an immensity of nuances is the condition of possibility of authorial discourse, and, as such, it is markedly distinct from the postmodern responses. But this authorial discourse is not monologically isolated, it is, rather, utterly dependent on a permanent confrontation with the 'infinite murmur' of surrounding discourses, including the discourse of literary tradition. For Kraus, this murmur is not the place of the 'death of the author', but, rather, the place where the self defines his identity by 'antropophagically' triumphing from that confrontation. The 'artist of the word' in Kraus's sense is, thus, not someone favoured with mystical capabilities, but the 'epigone' who is able to achieve that triumph and who, in that dialogical process, is literally endowed with authority - an authority he will have to prove and reassert again and again in the unending play of language.

\section{NOTES ON CONTRIBUTOR}

António Sousa Ribeiro is full professor for German Studies at the University of Coimbra. He has published extensively on several topics in Austrian and German Studies (with special emphasis on Karl Kraus and Viennese modernity), Comparative Literature and Cultural Studies. He has recently coorganized the volume Einschnitte. Signaturen der Gewalt in textorientierten Medien (Stuttgart: Königshausen \& Neumann, 2016).

$4^{\circ}$ Georg Knepler, Karl Kraus liest Offenbach. Erinnerungen, Kommentare, Dokumentationen (Berlin: Henschelverlag Kunst und Gesellschaft, I984), p. I78. See Karl Kraus, Zeitstrophen, ed. by Christian Wagenknecht (Frankfurt a.M.: Suhrkamp, I992), pp. 523-25.

${ }^{41}$ See Ribeiro, 'Karl Kraus and Modernism'. 